\title{
PARA CONHECER: Sociolinguística.
}

COELHO, Izete Lehmkuhl, GÖRSKI, Edair Maria et alii. São Paulo: Editora Contexto, 2015, 174 p.

O fascínio dos estudos linguísticos não perdeu o seu charme e o seu interesse, independentemente do público leitor, pois todos se interessam em saber como funciona a comunicação verbal no seio da sociedade. E esta é uma tarefa da Sociolinguística. Esta é uma ciência nova, que não tem 300 anos, porém desfruta de um apelo leitor interessante e enciclopédico. Neste caso, os autores procuraram situar os fenômenos dessa ciência ao nível de todo leitor.

5 capítulos, uma Apresentação, 25 tabelas e gráficos, um poema, uma seção de biografia dos autores, um designer gráfico de capa, 2 orelhas e uma seção de Apresentação bibliográfica. Tudo isto compõe o trabalho esmerado, instrutivo e rico de textos dos autores acima referidos.

A Sociolinguística é uma irmã rica de conteúdos da Filologia, da Linguística, da Psicolinguística, da Neurolinguística, da Gramática, da Teoria do Texto, da Pragmática e da Estilística. Como se observa, é uma ciência abrangente.

É sempre interessante conhecermos como as pessoas usam o idioma nacional em seus contatos diários, ora utilizando variantes-padrão, ora usando gírias, ora escrevendo no discurso formal, ora fazendo poemas e prosa. Em todos esses momentos, o objetivo dos textos é agir no meio social em que trabalha o fenômeno da Sociolinguística. Neste particular os autores dão uma aula interessante sobre a variação lexical, fonológica, discursiva e estilística.

À página 25, por exemplo, eles dizem:

Vários estudos sociolinguísticos atestam variação fonológica em diversos fenômenos do português do Brasil. Para exemplificar esse tipo de variação, observe a troca de $<\mathrm{h}\rangle$ por $<\mathrm{i}>$ nas palavras Paia (por 'palha'), muié (por 'mulher'), veia (por 'velha'), foia (por 'folha'), trabaio (por 'trabalho').

Um ponto interessante destacado pelos autores são os condicionadores, isto é, fatores que regulam a escolha do falante. Neste caso, realça-se o repertório lexical do usuário da língua, a exemplo de esposa, mulher, companheira, ajudante, anjo etc. Estas escolhas, portanto, dizem respeito também à situacionalidade do circuito da fala e da comunicação, 
território por excelência do discurso.

Outro ponto interessante é a análise dos estereótipos (no nosso caso, o T maranhense) de D e T; os marcadores, a exemplo de TU e VOCÉ e, finalmente, indicadores, na pronúncia do ditongo El, como em PEIXE/ PEXE; COUVE/COVE.

É uma leitura altamente recomendável ao grande público leitor que se interessa pelas louçanias da língua usada entre as classes sociais. 